40th Anniversary

\title{
GaN系半導体レーザーの高出力化と長波長化への道程
}

\author{
枡井 真吾, 長濱 慎一 \\ 日覀化学工業 (株) 第二部門開発本部第三開発部（テ774-8601 徳島県阿南市上中町岡491番地）
}

\section{Road to Higher Optical Output Power and Longer Wavelength of GaN Based Semiconductor Laser Diodes}

\author{
Shingo MASUI and Shin-ichi NAGAHAMA \\ Development Division Optoelectronics Products BU. Nichia Corporation \\ 491 Oka, Kaminaka-cho, Anan-shi, Tokushima 774-8601
}

(Received August 21, 2013)

\begin{abstract}
AlInGaN is most attractive material due to a directive semiconductor materials covering wide band energy ranging $0.8-6.4 \mathrm{eV}$. AlInGaN based violet semiconductor laser diodes (LD) is first demonstrated by Nichia Corporation in 1995. Since it, AlInGaN based LDs device characteristics have been improving and its lasing wavelength are expand from UV, blue, to green. In this paper, the technology histories of higher power and longer wavelength GaN based LDs are reviewed. Also, recent high optical power watt class blue and green LDs characteristics are introduced.
\end{abstract}

Key Words: GaN, Laser diodes, Visible laser

1.はじめに

$\mathrm{GaN}$ 系半導体 $\mathrm{Al}_{x} \mathrm{In}_{\mathrm{y}} \mathrm{Ga}_{(1-\mathrm{x}-\mathrm{y})} \mathrm{N}$ は, 深紫外〜赤外まで $(0.8$ $-6.4 \mathrm{eV})^{1,2}$ という広範囲のバンドギャップエネルギーを カバーする直接遷移型の化合物半導体材料である. 発光 デバイスとしての研究が盛んに進められており, 発光ダ イオード(Light Emitting Diode: LED)の分野では, 青色 LED と黄色蛍光体と組み合わせた白色 $\mathrm{LED}^{3)}$ が高効率, 長寿命の光源として液晶用バックライトや照明等に幅広 く普及している. 半導体レーザー (Laser Diode: LD) の分 野では, 1995年に電流注入によるレーザー発振(波長： $410 \mathrm{~nm})^{4)}$ が初めて実現した。 それ以降, 半導体レー ザーデバイスとしての性能は飛躍的に向上し, 現在では Blu-rayデイスクに代表される大容量光ディスクに広く 普及している，また近年では，GaN系半導体レーザーの 広带域化の開発が進み, 発振波長帯はUV領域から可視 光である青色, 緑色域まで広がっておりり ${ }^{5-7)}$, 露光, バ イオ等の分野において, 気体レーザーやランプの代替光 源として用途を広げている. 近年では可視光領域の青色 と緑色領域の半導体レーザーが, 光の三原色として利用 できるため, レーザーディスプレイ用の光源 ${ }^{8}$ として大 きく注目されている.

本稿ではGaN系半導体レーザーの発展について述べた 後, 近年その開発の進展が著しい青色㧍よび緑色半導体
レーザーの開発状況について概説する.

\section{GaN系半導体レーザーの発展}

\section{1 自立GaN基板}

GaN系半導体材料の大きな技術課題としてホモエピ夕 キシャル用のバルク GaN基板の欠如があった，一般的な LEDの作製に抢いては，サファイア基板上にエピタキ

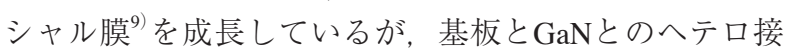
合に起因する結晶欠陌(貫通転位)が多数発生している.

このような結晶欠陥は駆動電流密度の低いLEDでは問題 とならなかったが, 半導体レーザーのように駆動電流密 度が高くなると, 結晶の劣化とともに発光効率を低下さ せてしまい, 実用デバイスとしての信頼性が得ることが できなかった，近年になり，異種基板上に高品位な $\mathrm{GaN}$ 結晶を得るためのELOG (Epitaxial Lateral Over Growth)成 長 $^{10)}$ のような低転位密度化技術やHVPEによる厚膜成長 技術の開発が飛躍的に進み, 低貫通転位密度の高品質自 立 $\mathrm{GaN}$ 基板 ${ }^{11,12)}$ の作製が可能となった。近年では, $\mathrm{Na}$ ラックス ${ }^{13,14}$ やアモノサーマル法 ${ }^{15-17}$ 等の新たな結晶成 長技術の開発も進んでいる。これら高品質な自立c面 $\mathrm{GaN}$ 基板の登場により, 高効率化が進みGaN系半導体 レーザーは実用デバイスとしての十分な信頼性が確保で きるようになり，Blu-rayディスクに代表される大容量 


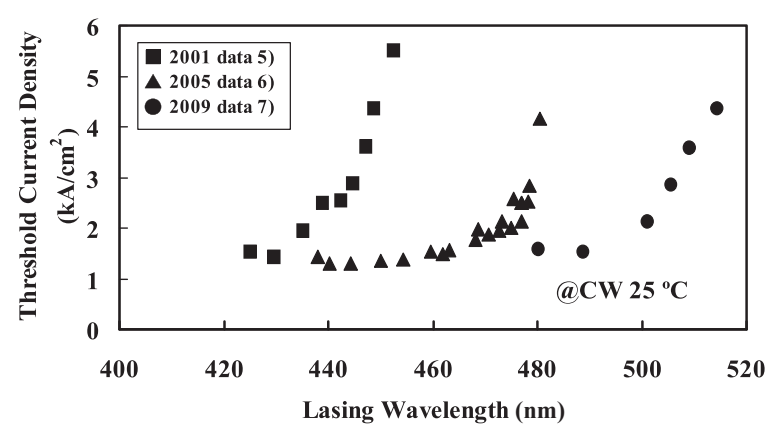

Fig. 1 Wavelength dependence of threshold current density of $\mathrm{c}$ face $\mathrm{GaN}$ based laser diodes.

光ディスク用の紫色半導体レーザー光源 ${ }^{18,19)}$ として製品 化され広く普及するようになった。

\section{$2.2 \mathrm{GaN}$ 系半導体レーザーの長波長化}

GaN系半導体レーザーの発振波長においては, 400〜 $420 \mathrm{~nm}$ の青紫色領域の発振波長のレーザーが比較的作 製しやすいとされる。これは青紫領域の半導体レーザー では, InGaN活性層のIn混晶やAlGaNクラッド層のAl混 晶を大きくする必要がないので，レーザー素子と基板で ある $\mathrm{GaN}$ と格子定数差が小さく容易にエピタキシャル 成長出来るためである。，一方，それより長波長領域にあ る青色〜緑色領域の半導体レーザーを実現するためには 種々の問題が発生してくる. Fig. 1にこれまでに報告さ れてきたc面 $\mathrm{GaN}$ 基板上の系半導体レーザーのしきい值 電流密度の発振波長依存性を示す ${ }^{5-7)}$. 半導体レーザー のしきい值電流密度は発振波長に大きく依存し, 長波長 化に伴い上昇していくことがわかる。この原因として， 基板との格子定数差の増大に伴う InGaN活性層の結晶劣 化および内部電界の増加 ${ }^{20-22}$ による発光効率の低下 (量 子シュタルク効果) や, 屈折率の波長分散に起因したエ ピタキシャル層内での光閉じ込めの低下などが挙げられ る。これらは長波長化に伴い影響がより大きくなるた め, 発振波長の長波長化を実現する際の壁となる。この ような多くの技術課題があるものの, 先述した高品質自 立 $\mathrm{GaN}$ 基板 ${ }^{11,12)}$ の採用やエピタキシャル成長条件，エピ タキシャル膜構造の最適化による内部電界の抑制, 光閉 じ込め構造の最適化等により, 発振波長の高効率化およ び長波長化が達成されており, 青色領域だけでなく緑色 領域のレーザー発振が実現され製品化されている。ま た，緑色領域のレーザーでは，c面 GaN基板上のレー ザー素子だけでなく, c 面GaNから面方位を傾けること によって内部電界を抑制した半極性(20-21) GaN基板上

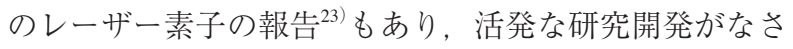
れている.

さらなる長波長領域である黄色や赤色 $\mathrm{GaN}$ 系半導体 レーザーにおいては未達の領域であり， InGaN基板等い くつかの新たなブレークスルーが必要になってくるもの と思われる。

\section{3. 青色・緑色半導体レーザー}

本項においては, 我々が開発しているc面 $\mathrm{GaN}$ 基板上
のワットクラスの高出力青色および緑色レーザーの現状 の諸特性を紹介しながら, GaN系半導体レーザーの現状 と今後について概説する。

\section{1 半導体レーザーの構造}

半導体レーザーの構造概念図をFig. 2に示す。基板と して，低転位密度のc面自立 GaN基板を用いた。この基 板上にMOCVD法(Metal Organic Chemical Vapor Deposition) を用いて, 高出力半導体レーザー素子として最適化した エピタキシャル成長を行った. $\mathrm{GaN}$ 系半導体レーザー素 子は $\mathrm{Al}_{\mathrm{x}} \mathrm{Ga}_{\mathrm{y}} \mathrm{In}_{1-\mathrm{x}-\mathrm{y}} \mathrm{N}$ 結晶によって構成され, 発光層には $\mathrm{InGaN}$ 量子井戸層を用いている。レーザーのデバイス構 造は一般的な屈折率導波型のリッジストライプ構造と し, リッジ部分の外側を絶縁膜で覆うことで, 水平横方 向の屈折率差を設けて横モードの制御を図っている。一 方, 垂直横モードの制御には, キャリアをInGaN多重量 子井戸発光層内部に，光をガイド層内部にそれぞれ分離 して効率的に閉じ込める分離閉じ込め構造(Separate Confinement Heterostructure: SCH)が，採用されている. レーザーの共振器端面はGaN基板のm面をへき開するこ とによって形成し, 共振器端面の前面側を低反射に, 裏 側は高反射にそれぞれ絶縁膜でコーティングを行った。

\section{$3.2 \mathrm{GaN}$ 系半導体レーザーの高出力化}

一般的に光出力が $1 \mathrm{~W}$ 超える高出力レーザーにはワ イドストライプ構造が採用される。これは半導体レー ザー特有の破壊モードである光学損傷 (Catastrophic Optical Damage: COD)による故障が発生しないように, レーザーの出射端面幅を広げて光密度を低減するためで ある。また，ワットクラスの高出力レーザーの駆動時に は，投入電力が大きくなるため， LD素子からの排熱性 も重要となる。光Disc向けなどの半導体レーザーでは $\phi 5.6 \mathrm{~mm} \phi 3.8 \mathrm{~mm}$ のANパッケージが多く用いられて いるが, これらは小型化を優先した設計であるため熱抵 抗が高く, ワットクラスのような高出力半導体レーザー を駆動する場合，温度上昇が問題となってしまう。半導 体素子の温度上昇は光出力や寿命の低下といった悪影響 を及ぼすことから，比較的熱抵抗が低く，半導体レー ザーパッケージとして汎用的である $\phi 9 \mathrm{~mm}$ の CANパッ

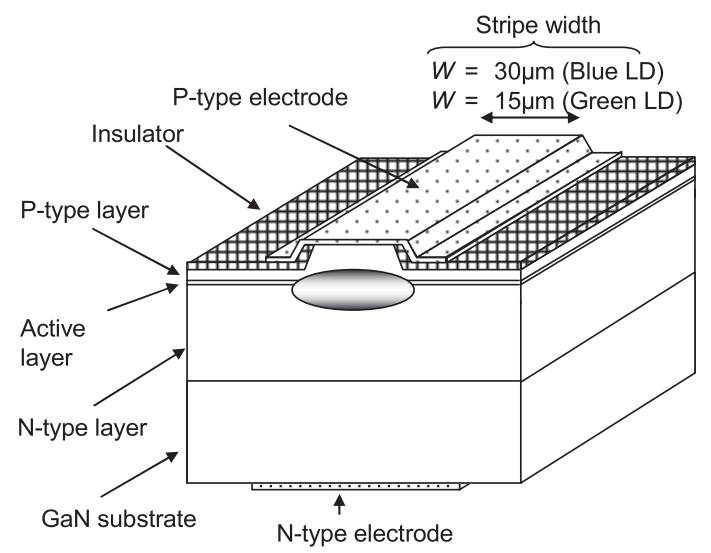

Fig. 2 Schematic structure of $\mathrm{GaN}$ based laser diodes. 


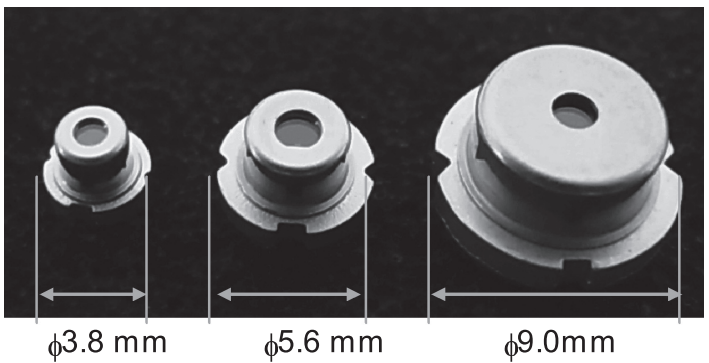

Fig. 3 Kinds of TO CAN packages of LDs.

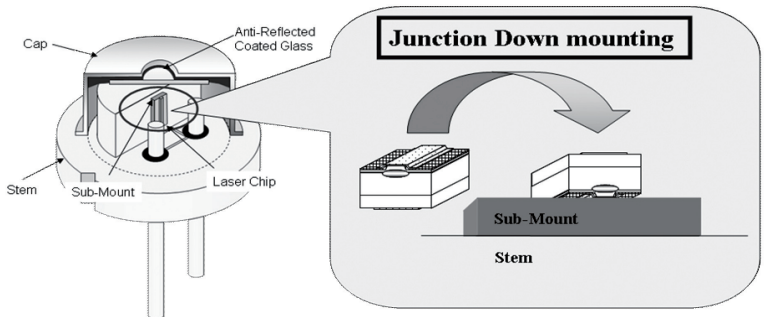

Fig. 4 Image of inside package and mounting method.

ケージを用いた Fig. 3). また更なる熱抵抗低減のため に, 発光層に近いp層側が放熱面となるジャンクション ダウン実装(Fig. 4)をおこなうことで，大幅に熱抵抗を 低減することができる.

次項よりこれらの高出力構造を採用し, 我々が開発し た青色および緑色 $\mathrm{GaN}$ 系半導体レーザーの最新の特性に ついて紹介する。

\section{3 青色高出力半導体レーザー}

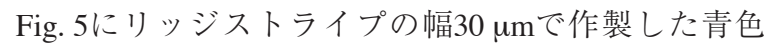
$\mathrm{LD}$ の電流 - 電圧 $(V-I)$, 電流 - 光出力 $(L-I)$ 特性を示す. ケース温度 $25^{\circ} \mathrm{C}, \mathrm{CW}$ 駆動時のしきい值電流 $\left(I_{\mathrm{th}}\right)$ は $225 \mathrm{~mA}$ であり, 駆動電流2.3 A 時の光出力, 駆動電圧は

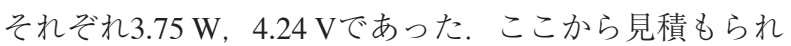
る光一電力変換効率 (Wall-Plug Efficiency: WPE) は $38.5 \%$

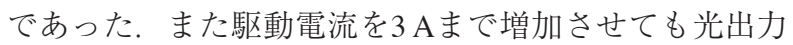
の飽和は起こらず， $5 \mathrm{~W}$ に迫る光出力が得られている。 これはLDチップの改良，パッケージ及びジャンクショ ンダウン実装による熱抵抗低減の効果によるものであ る.

Fig. 6に駆動電流2.3 A 時の発振スペクトルを示す。発 振波長は450 nmであり，縦マルチモードで発振してい る。また遠視野像 (Far Field Pattern: FFP) をFig. 7に示 す。 $30 \mu \mathrm{m}$ というストライプ幅を反映して成長面に対し て水平方向 $\left(\theta_{\|}\right)$では高次モードが発生し, 台形状の放射 モードになっていることがわかる。広がり角は強度が ピークの $1 / e^{2}$ となる角度で定義した場合，水平方向が $14^{\circ}$, 垂直方向が $42^{\circ}$ の成長方向に長い放射形状とな る.

次に青色LDの温度特性について述べる. Fig. 8はCW

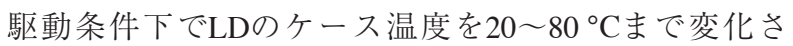
せ，L-I特性を測定した結果である。ケース温度 $80{ }^{\circ} \mathrm{Cに}$ おいても光出力は飽和しておらず，WPEは $34.7 \%$ (駆動 電流2.3 A時)であることを確認した。また発振波長の温 度依存性(Fig. 9) から, 温度上昇に伴う発振波長の長波

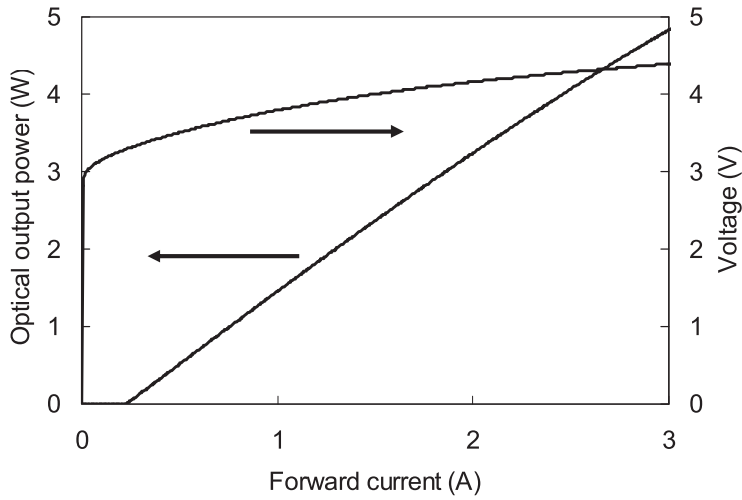

Fig. 5 Typical $L-I$ and $V-I$ characteristics of high-power blue LDs under $25^{\circ} \mathrm{C}-\mathrm{CW}$ operation.

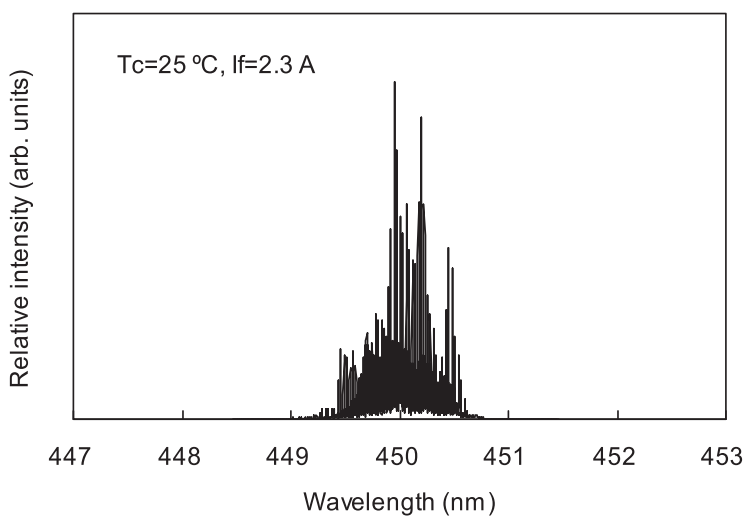

Fig. 6 Typical spectrum characteristics of high-power blue LDs under $25^{\circ} \mathrm{C}-\mathrm{CW}$ operation.

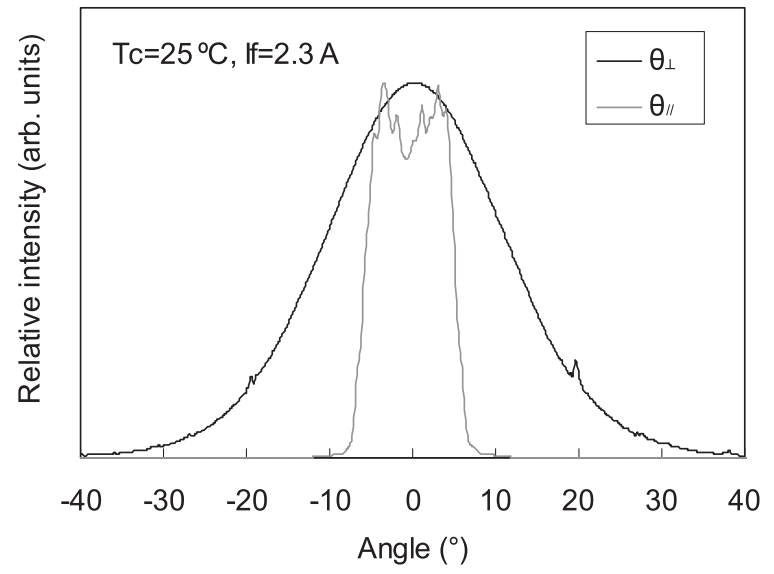

Fig. 7 Typical FFP in perpendicular $\left(\theta_{\perp}\right)$ and parallel $\left(\theta_{/ /}\right)$ of high-power blue LDs.

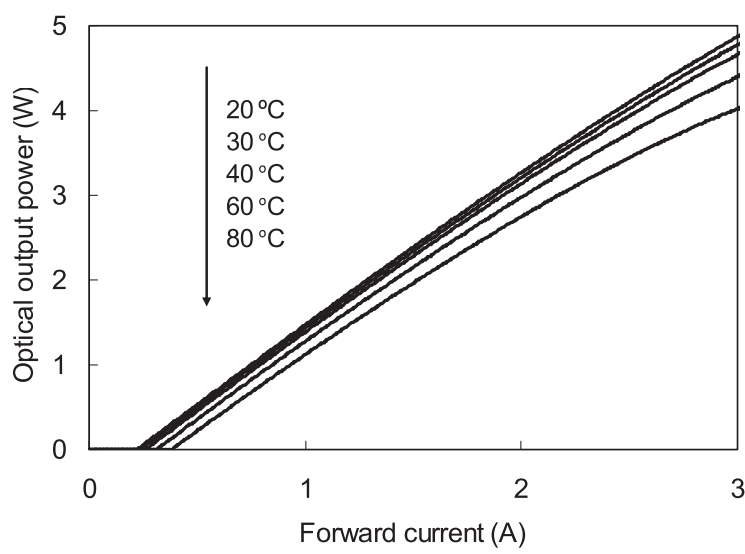

Fig. 8 Temperature dependence of L-I characteristics for high-power blue LDs. 


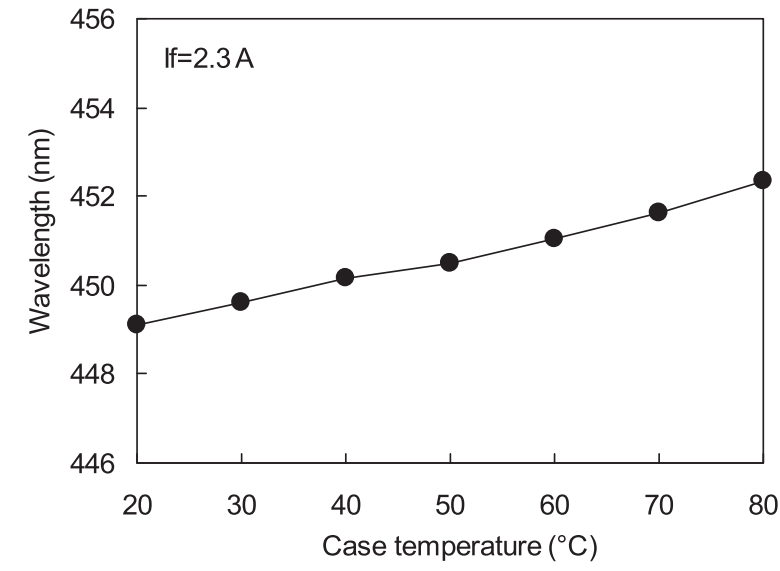

Fig. 9 Temperature dependence of lasing wavelength for high-power blue LDs.

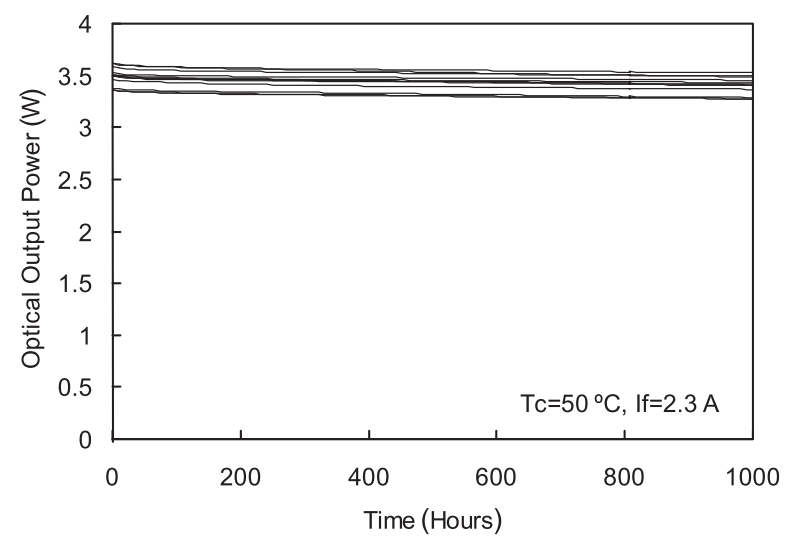

Fig. 10 Aging data operating at $2.3 \mathrm{~A}$ and $50{ }^{\circ} \mathrm{C}$ under automatic current control.

長化は $0.04 \mathrm{~nm} /{ }^{\circ} \mathrm{C}$ 程度であり, 温度変化に対する波長シ

フトは赤色LDの $0.20 \mathrm{~nm} /{ }^{\circ} \mathrm{C}$ よも小さい.

寿命特性はLDのケース温度を $50{ }^{\circ} \mathrm{C} と し$, 駆動電流を $2.3 \mathrm{~A}$ とて光出力の変化から評価を行った (Fig. 10). 光 出力が初期の半分になる時間 (半減期)を寿命とした場 合, 1000 時間通電後の劣化係数 $(\Delta L / \Delta t)$ より平均寿命は 30,000時間以上と見積もられた。

\section{4 緑色高出力半導体レーザー}

Fig. 11にリッジストライプの幅15 $\mu \mathrm{m}$ で作製した波長 $525 \mathrm{~nm}$ の緑色LDのV-I, L-I特性を示す。 ケース温度

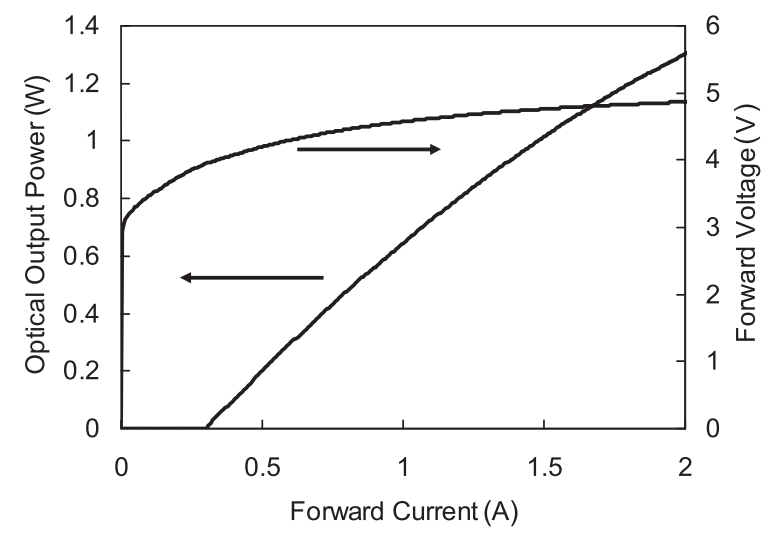

Fig. 11 Typical $L-I$ and $V-I$ characteristics of high-power green LDs under $25^{\circ} \mathrm{C}-\mathrm{CW}$ operation. $25^{\circ} \mathrm{C}, \mathrm{CW}$ 駆動時のしきい值電流は300 mAであり, 駆 動電流 $1.5 \mathrm{~A}$ において光出力 $1 \mathrm{~W}$ 実現している。この際

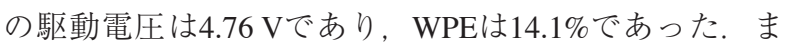
た2 Aまで駆動電流を増加させても光出力の飽和は起こ らないことを確認した。 Fig. 12は駆動電流1.5 Aにおける 発振スペクトルである。青色LD同様, 縦マルチモード で発振を確認できた。

$L-I$ 特性, 発振波長の温度特性も青色同様, CW駆動に

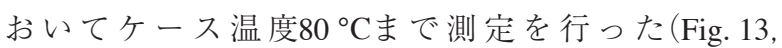
Fig. 14 ; 波長 $520 \mathrm{~nm}$ ). 光出力の低下は青色に比べて若

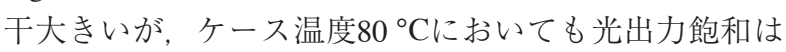

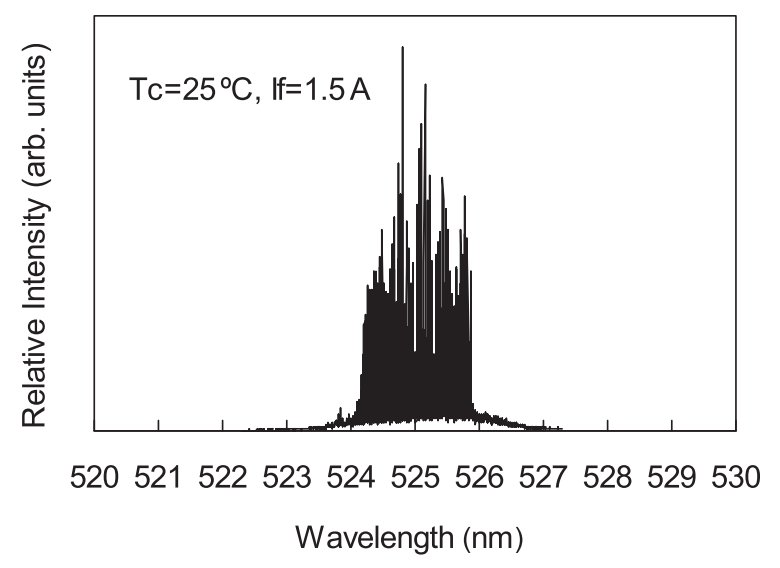

Fig. 12 Typical spectrum characteristics of high-power green LDs under $25^{\circ} \mathrm{C}-\mathrm{CW}$ operation.

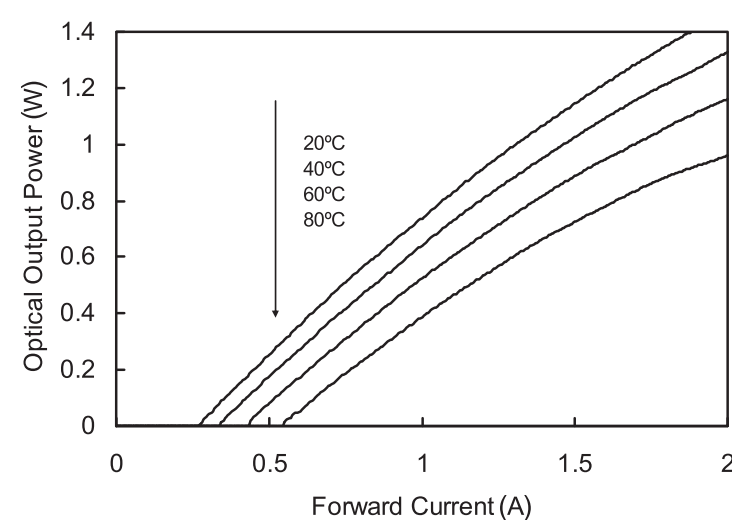

Fig. 13 Temperature dependence of $L-I$ characteristics for high-power green LDs.

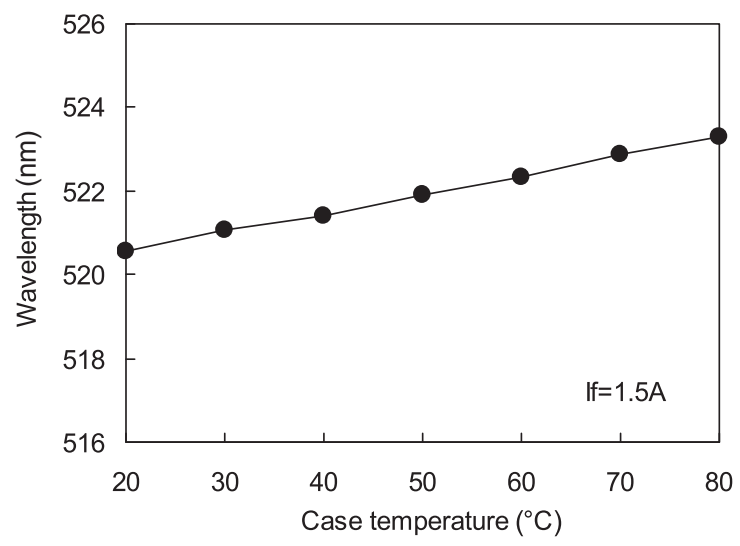

Fig. 14 Temperature dependence of lasing wavelength for high-power green LDs. 


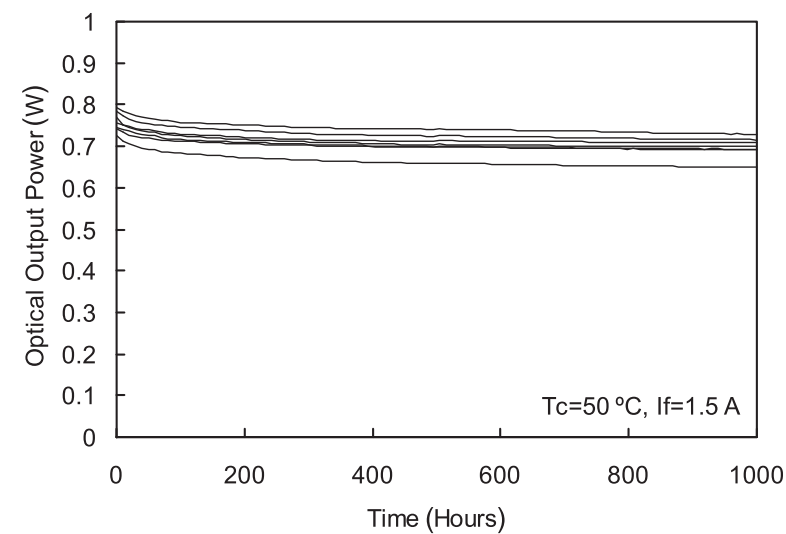

Fig. 15 Aging data operating at $1.5 \mathrm{~A}$ and $50{ }^{\circ} \mathrm{C}$ under automatic current control.

発生していないことがわかる，波長の温度シフトに関し ても青色LDとほぼ同等の $0.05 \mathrm{~nm} /{ }^{\circ} \mathrm{C}$ 程度であった。

寿命特性は波長520～525 nmのLDを使用し，ケース温 度 $50{ }^{\circ} \mathrm{C}$, 駆動電流 $1.5 \mathrm{~A}$ とて光出力の変化から評価を 行った (Fig. 15). 寿命を青色と同様に半減期で定義した 場合, 1,000 時間通電後の劣化係数から平均寿命は 10,000 時間以上と見積もられた。

\section{$3.5 \mathrm{GaN}$ 系半導体レーザーの現状}

GaN系半導体レーザー用基板において，量産実績のあ る光ディスク用の青紫色半導体レーザー（波長： $405 \mathrm{~nm}$ ) と同じc面 $\mathrm{GaN}$ 基板が一般に多く用いられてい る. 半導体レーザーを放射光特性で分類すると, 横モー ドマルチとシングルの2つに分けられる。青色，および 緑色 $\mathrm{GaN}$ 系半導体レーザーの最近の主な研究機関からの 報告をTable 1 によめる。

ワットクラスの光出力を実現できる横モードマルチの 高出力レーザーでは主にc面 $\mathrm{GaN}$ 基板が用いられており,

Table 1 Comparisons in multi and single transverse mode blue and green LDs.

\begin{tabular}{|c|c|c|c|c|}
\hline \multirow{2}{*}{\multicolumn{2}{|c|}{$\begin{array}{c}\text { Transverse mode } \\
\text { Color }\end{array}$}} & \multicolumn{3}{|c|}{ Multi mode } \\
\hline & & \multicolumn{2}{|c|}{ Blue } & Green \\
\hline \multicolumn{2}{|l|}{ Researcher } & Nichia & Osram & Nichia \\
\hline \multicolumn{2}{|c|}{ Orientation of $\mathrm{GaN}$} & $(0001)$ & $(0001)$ & $(0001)$ \\
\hline \multicolumn{2}{|c|}{ Wavelength (nm) } & 450 & 450 & 525 \\
\hline \multicolumn{2}{|c|}{ Optical output power (W) } & 3.75 & $\sim 2.5$ & 1.0 \\
\hline \multicolumn{2}{|l|}{ WPE (\%) } & 38.5 & $\sim 29$ & 14 \\
\hline \multicolumn{2}{|l|}{ Reference } & this paper & 24) & this paper \\
\hline \multicolumn{2}{|l|}{ Transverse mode } & \multicolumn{3}{|c|}{ Single mode } \\
\hline Color & \multicolumn{2}{|c|}{ Blue } & \multicolumn{2}{|c|}{ Green } \\
\hline Researcher & Nichia & Osram & Osram & SEI/SONY \\
\hline Orientation of $\mathrm{GaN}$ & $(0001)$ & $(0001)$ & $(0001)$ & $(20-21)$ \\
\hline Wavelength (nm) & 445 & 452 & 520 & 525 \\
\hline WPE $(\%)$ & 18.9 & 18.3 & 8.9 & 8.9 \\
\hline Reference & $※$ & 25) & 26) & 23) \\
\hline
\end{tabular}

※From Nichia's homepage (Model: NDB4116E).
青色領域においてOsramの研究グループから光出力は $2.5 \mathrm{~W}$ で確認され, WPEは最大 $29 \%$ 得られていると 報告されている24). 日覀化学では, 先述したように動作 電流 $2.3 \mathrm{~A}$ 時に光出力 $3.75 \mathrm{~W}, \mathrm{WPE} 38.5 \%$ と高効率の レーザーが実現できており，緑色領域でも動作電流 $1.5 \mathrm{~A}$ 時の発振波長 $525 \mathrm{~nm}$, 光出力 $1.01 \mathrm{~W}, \mathrm{WPE} 14.1 \%$ と青色レーザーに比べると劣るもののワットクラスの半 導体レーザーを実現している。

横モードシングルのレーザーでは，青色領域におい て, Osramの研究グループから, 光出力 $100 \mathrm{~mW}$ 時に, WPEとして $18.3 \%{ }^{25)}$, 日亜化学からはWPEは $18.9 \%$ と報 告されている。緑色領域において, Osramの研究グルー プから, c面GaN基板を用いて $520 \mathrm{~nm}$ の発振波長で WPE $8.9 \%{ }^{26)}$ の報告がなされた.

一方で, c面 $\mathrm{GaN}$ 基板上だけでなく，半極性面である (20-21) GaN基板上に成長した横モードシングルの緑色 半導体レーザーの報告がある. c面 $\mathrm{GaN}$ 基板上のレー ザー素子では高いIn組成のInGaN発光層の結晶性の悪化 の問題以外にも，ピエゾ電界による量子閉じ込めシュ夕 ルク効果による発光効率の低下の問題がおきている.

Fig. 16に電流注入時におけるc面GaN基板上の緑色領域 のInGaN活性層のバンド構造およびキャリア濃度のシ ミュレーション結果を示す。ピエゾ電界の強さは理論值 の1/2で計算を行っている。 ピエゾ電界の発生により, バンド構造は大きく曲がり, 電子と正孔のキャリア濃度 の分布に偏りがあることがわかる.このため, 電子と正 孔の波動関数の重なりが減少し, 結果として再結合して 発光する割合が低下してしまうのである。この問題を解 決するために，c軸から傾けた面，つまり非極性や半極 性の $\mathrm{GaN}$ 基板を利用することにより，成長方向のピエゾ 電界強度を低減させる試みがなされている。このような 利点を生かして住友電工とSONYの研究グループから, (202-1) 半極性面 GaN基板上に作製した緑色半導体レー ザーにおいて, $525 \mathrm{~nm}$ の発振波長でWPE. $8.9 \%$ を報告 している。しかしながら，半極性基板を用いた緑色LD の効率はc面 $\mathrm{GaN}$ 基板のそれと顕著な差がなく，極性面 (c面) および半極性面を含めた緑色LDのWPEは青色LD

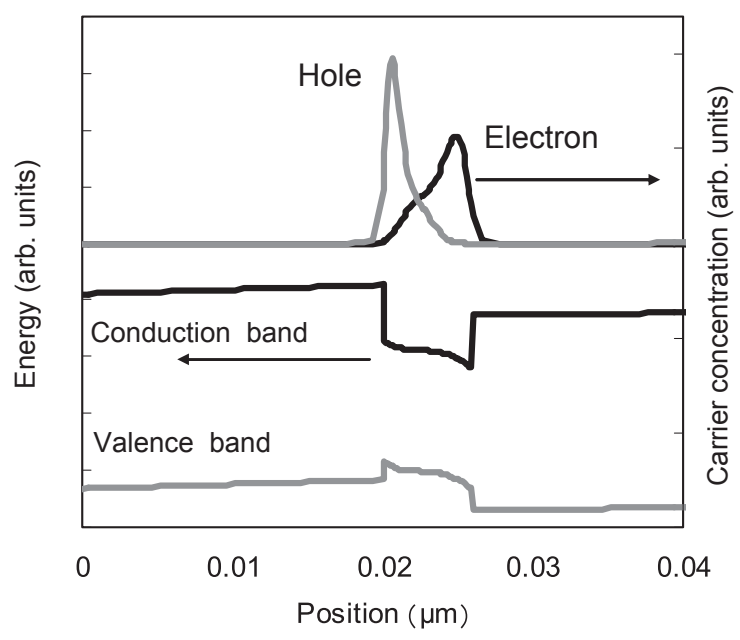

Fig. 16 Simulation results of Green active layer band structure and carrier concentration. 
の半分程度しかないのが現状である。

今後，さらなる高効率化および長波長化のためには， たとえば高In組成比の発光層InGaNに格子整合する高品 位InリッチInGaN基板，もしくはInNの実現などの新た なブレークスルーが必要と思われる。

\section{4. まとめ}

本稿では GaN系半導体レーザーの発展および青色, 緑 色半導体レーザーの開発状況について解説した。青色領 域だけでなく緑色領域においてもワットクラスの光出力 の半導体レーザーが実現され，すでに実用化されている 赤色LDと合わせ, 光の三原色のワットクラス半導体 レーザー光源が出揃うことになった。これらの半導体 レーザーを光源として用いたディスプレイやプロジェク 夕の開発および製品化がさらに加速され，市場が活発に なっていくことを期待する。さらなる高出力化において は, LD素子の効率改善はもちろんのこと, マルチスト ライプやアレイ構造の導入, TO-CANパッケージ以外の 低熱抵抗パッケージの採用などにより，効果的に実現で きると思われる。また，さらなる長波長化には高品位In リッチ $\mathrm{InGaN}$ 基板，もしくは $\mathrm{InN}$ 基板の実現など新たな ブレークスルーが必要と思われる.

\section{参考文献}

1) J. Wu, W. Walukiewicz, K. M. Yu, J. W. Ager III, E. E. Haller, H. Lu, W. J. Schaff, Y. Saito, and Y. Nanishi: Appl. Phys. Lett. 80 (2002) 3967.

2) W. M. Yim, E. J. Stofko, P. J. Zanzucchi, J. I. Pankove, M. Ettenberg, and S. L. Gilbert: J. Appl. Phys. 44 (1973) 292.

3) K. Bando, K. Sakano, Y. Noguchi, and Y. Shimizu: J. Light \& Vis. Env. 22 (1998).

4) S. Nakamura, M. Senoh, S. Nagahama, N. Iwasa, T. Yamada, T. Matsushita, H. Kiyoku, and Y. Sugimoto: Jpn. J. Appl. Phys. 35 (1996) L74.

5) S. Nagahama, M. Sano, T. Yanamoto, and T. Mukai: Jpn. J. Appl. Phys. 40 (2001) 3075.
6) T. Kozaki, T. Yanamoto, T. Miyoshi, Y. Fujimura, S. Nagahama, and T. Mukai: SID Digest, Boston, May, (2005) pp1605.

7) T. Miyoshi, S. Masui, T. Okada, T. Yanamoto, T. Kozaki, S. Nagahama, and T. Mukai: Appl. Phys. Express 2 (2009) 062201.

8）山本 和久：レーザー研究 41 (2013) 300.

9) H. Amano, N. Sawaki, I. Akasaki, and Y. Toyoda: Appl. Phys. Lett. 48 (1986) 353.

10) A. Usui, H. Sunakawa, A. Sasaki, and A. Yamaguchi: Jpn. J. Appl. Phys. 37 (1997) L899.

11) K. Motoki, T. Okahisa, N. Matsumoto, M. Matsushima, H. Kimura, H. Kasai, K. Takemoto, K. Uematsu, T. Hirano, M. Nakayama, et al.: Jpn. J. Appl. Phys. 40 (2006) L140.

12) Y. Oshima, T. Eri, M. Shibata, H. Sunakawa, K. Kobayashi, T. Ichibashi, and A. Usui: Jpn. J. Appl. Phys. 42 (2003) L1.

13) A. Yoshikawa, E. Ohshima, T. Fukuda, H. Tsuji, and K. Oshima: J. Cryst. Growth 260 (2004) 67.

14) J. A. Jejier, S. McKernan, A. P. Purdy, W. L. Gladfelter: Chem. Mater. 12 (2000) 1003.

15) D. R. Ketchum and J. W. Kolis: J. Cryst. Growth 222 (2001) 431.

16) H. Yamane, M. Shimada, T. Sekiguchi, and F. J. DiSalvo: Chem. Mater. 9 (1997) 413.

17) Y. Mori, Y. Kitaoka, M. Imade, N. Miyoshi, M. Yoshimura, and T. Sasaki: Physica Status Solidi (c) 8 (2011) 1445.

18) S. Nagahama, N. Iwasa, M. Senoh, T. Matsushita, Y. Sugimoto, H. Kiyoku, T. Kozaki, M. Sano, H. Matsumura, H. Umemoto, et al.: Jpn. J. Appl. Phys. 39 (2000) L647.

19) T. Tojyo, S. Uchida, T. Mizuno, T. Asano, M. Takeya, T. Hino, S Kijima, S. Goto, Y. Yabuki, and M. Ikeda: Jpn. J. Appl. Phys. 41 (2002) 1829

20) S. Chichibu, T. Azuhata, T. Sota, and S. Nakamura: Appl. Phys. Lett. 69 (1996) 4188.

21) T. Takeuchi, S. Sota, M. Katsuragawa, M. Komori, H. Takeuchi, H. Amano, and I. Akasaki: Jpn. J. Appl. Phys. 36 (1997) L382.

22) T. Takeuchi, H. Amano, and I. Akasaki: Jpn. J. Appl. Phys. 39 (2000) 413.

23) S. Takagi, Y. Enya, T. Kyono, M. Adachi, Y. Yoshizumi, T. Sumitomo, Y. Yamanaka, T. Kumano, S. Tokuyama, K. Sumiyoshi, et al.: Appl. Phys. Express 5 (2012) 082102.

24) A. Avramescu, C. Eichler, T. Hager, T. Lermer, C. Vierheilig, S. Tautz, A. Lell, J. Müller, F. Kopp, B. Stojetz, et al.: Laser Display Conference '12 (2012) LDC1-1.

25) S. Lutgen, D. Dini, I. Pietzonka, S. Tautz, A. Breidenassel, A. Lell, A. Avramescu, C. Eichler, T. Lermer, J. Müller, et al.: Proc. SPIE. 7953 (2011) 795315

26) G. Bruederl, T. Hager, C. Vierheilig, C. Eichler, S. Tautz, B. Stojetz, T. Lermer, A. Avramescu, and U. Strauß: 2013 Conference on Lasers and Electro-Optics Pacific Rim (CLEO-PR) SA1-2. 